\title{
Taiwan Halal Tourism Industry: Policy and Practice
}

\author{
Rita Pawestri Setyaningsih \\ \{rita_pawestri@yahoo.com\} \\ Center for Area Studies, Indonesian Institute of Sciences, Indonesia
}

\begin{abstract}
Recently, halal tourism has become an emerging phenomenon in the world. Taiwan as the Muslim-minority region has also paid more attention to develop halal tourism industry. The growing number of Muslim populations in the world has been seen as the major potential market for halal market, trade and tourism. This strategy is part of the NSP launched in 2016. Though still at the early stage of development, Taiwan has shown achievement. This good performance might be influenced by supportive tourism policy. Two main areas have become the focus of the development, namely accommodation, and restaurant. This study will investigate policy and practice of halal tourism development in Taiwan. The policy that develops or promotes tourism is supposed to result maximum social and economic benefit to nation, region or locality. Many scholars have investigated halal tourism industry development but limited research has been done for the case of Taiwan. This research uses qualitative approach by using interview. Data was collected through desk and field research in Taipei and Taichung. Structured interviews with some stakeholders were conducted. Analysis is done descriptively by using policy approach. The research found that in developing the halal tourism industry in Taiwan, there is no explicit halal industry development policy and exact plan of action how to support the policy implementation. In practice, Taiwan's efforts to promote halal certification and to create Muslim-friendly environment. Five categories of halal certification have been issued by four different halal certified bodies. A few numbers of Taiwan culinary becomes challenge to develop Taiwan halal tourism. subsidy program to promote the Muslim friendly restaurant was not well informed to the businessman.
\end{abstract}

Keywords: Taiwan, Halal Tourism, Policy, Practice

\section{Introduction}

Recently, halal tourism has become an emerging phenomenon in the world [1][2]. Though Arab world was the pioneer ${ }^{1}$ in developing the halal tourism, nowadays other countries have also paid more attention to develop the halal tourism, including the non-Muslim countries like Canada, Hong Kong, Australia [2], Japan, South Korea and Taiwan. The growing number of Muslim populations in the world has been seen as the major potential market for halal market, trade and tourism. Pew Research Centre [3] noted that in 2010 the total population of the Muslim world was around 1.7 billion, representing $23 \%$ of the world's population. The number increased

${ }^{1}$ Historically, the emerged of the halal tourism was started as a result of the booming of petrodollar. The boom of the oil business in the Middle East encouraged the need of Islamic banking as a place to manage finance with non-interest based. Further, this generated the development of Syaria banking business that develops into the other countries, including the UK, Swiss and so on [6]. Then, the halal tourism industry expands into the other business, into the lifestyle including tourism, hospitality, recreation, medical care, fashion, cosmetics, etc. The fastest growing of Muslim population as well as their high purchasing power become factors of generator of this demand. 
to 1.8 billion or $24.1 \%$ of the total world population in 2015 and will increase to 2.2 billion people by 2030 or represents $26.4 \%$ of the projected population of 8.3 billion [4]. According to the estimation of the Crescent rating [5], between 2015 and 2060, Muslim demographics will grow more than twice as fast as the overall growth in the world population. While the world population is projected to grow by $32 \%$ in the same period. Whereas according to the Thomson Reuters Global Islamic Report Economy in 2017 Muslim's consumption's biggest products were food, tourism, cloth, formation, media/recreation, cosmetics, which accounted for USD 2 trillion or equals to $11.9 \%$ of the total consumption of the People's Republic of China's consumption in those 6 sectors [6]. Regarding consumer spending, in 2015 spending in the food and lifestyle sector generated around US\$ 1.9 trillion. In 2021, this market is expected to grow to US \$ 3 trillion. Meanwhile research by The Mastercard-Halal Trip Muslim Millennial Travel Report 2017 estimates that the expenditure of Muslim tourists as a whole will reach USD 300 billion by 2026 [7].

Since Taiwan launched the New Southbound Policy (NSP) in 2016, halal tourism has been included as one of the platforms of the policy and has been developed more intensively. Among the four strategic policies in the NSP, developing the halal tourism industry is included in flagship of the resource sharing.

Topic of the Taiwan halal Tourism is interesting to be searched considering that Taiwan is predominated by Buddhist and Taoist society, but it has also been trying to develop halal tourism industry. Though still at the early stage of development, in fact, Taiwan's efforts have shown an achievement. Based on the Global Muslim Travel Index 2019, among the non-OIC destinations, Taiwan ranked number 5 as the top destination of Muslim traveler, just after Singapore, Thailand, UK, and Japan (Crescent rating, 2019). Hence, it can be said that Taiwan is quite successful in developing its halal tourism industry. This study argues that this good performance might be contributed by the support of the policy on the development of the halal tourism industry.

Table 1. Taiwan's rank among the non-OIC destinations in the GMTI (2015-2019)

\begin{tabular}{|c|c|c|c|c|c|}
\hline Year & 2015 & 2016 & 2017 & 2018 & 2019 \\
\hline Rank & 10 & 7 & 7 & 5 & 5 \\
\hline
\end{tabular}

Source: Crescent Rating Global Muslim Travel Index (GMTI), various years.

Many scholars have investigated the application of halal tourism in many places [6][8][9][10][11]. Even though Muslim-friendly tourism in Taiwan has become a trending issue among scholars, very limited research has been carried out. For example, Mohsin, Ramli and Alkhulayfi [1] conduct study on the halal tourism: emerging opportunities. They explain about the growing trends of the halal tourism market segment and identify some basic information about this segment, such as the definition of halal tourism, the source of information, and the potency of halal tourism. The method of the research was based on the secondary resources. However, little explanation of the research was about authority body or institutions that give halal certification in eight countries, both the Muslim-majority countries and Muslim-minority countries, including Taiwan. Hence, it can be said that information of the halal tourism in Taiwan was so limited.

Adham [12] conducts a research on the "Halal Taiwan: Emerging Player in the Global Halal Market". His research focuses on the existence operation of halal industry in Taiwan and analyzes some potential for sustainable growth and facing global competitiveness. He explains some aspects and analyses it from systematic perspective, including the halal certification bodies, halal products providers and other related bodies in their value chain such as the 
supplying and retailing business in Taipei. His study finds that the halal industry in Taiwan is characterized by stringent certification procedures that emphasizes of getting recognition from reputable international halal certification bodies. The halal certification process is implemented by multiple certification bodies and mostly private driven while there is absence of the role of the Taiwan's administration involvement in administering the affairs of the development of the halal industry. However, his study focuses more on the halal products in Taiwan, and does not discuss in detail about the halal tourism industry in Taiwan.

In addition, Battour and Ismail [13] that review the halal tourism: concept, practices, challenges and future mention that halal tourism gets more attention for both the perspectives of industry and research. By using secondary resources, the study mentions that the success of developing and marketing halal tourism destination has to adopt Islamic teaching and principles. They explain some concepts of the halal tourism with the components within the industry. They also give some examples of the current best practices of the Muslim-minorities countries such as Japan, the Philippines, and Brazil. Though halal tourism is such a good business opportunity for Taiwan, they don't explain it further.

Yang [14] that conducts research on the "Traditional Market consumers' care about the halal meat label" picks up a case on Taiwan, focuses on the willingness to purchase of the halallabeled chicken. The study finds that although the attribute of religious norms influences a small group of consumers, majority of the consumer of the halal labeled chicken in traditional market are attracted to buy it due to the factors of cleanliness, and animal welfare. These factors, further, are recommended to be part of the marketing strategy and development of local halal food product for the government and enterprises.

A study by Lin et al. as cited by Yilmaz and Gultekin [15] based on the interview with tourism officials and 83 people working as senior executives, finds that the most attractive factor about tourists experience the cuisine of Taiwan is participating in the local festivals, gourmet tours and holidays. Besides, Taiwan has gastronomy destination identity with its various and different local foods.

From the above-mentioned literatures show that the existing literatures on Taiwan halal tourism industry are very limited and there is still gap for further research: No research on the policy of the halal tourism development in Taiwan and how it is practiced. Hence, this study is expected to fulfill the gap. This research is trying to answer two questions: How does Taiwan's policy on the halal tourism industry development and how it is implemented from the perspective of businesspeople?

This study is aimed to understand the policy that supports the development of the halal tourism industry in Taiwan and to understand the implementation of the policy.

\section{Methods}

This is a qualitative research. Data was collected through desk research to obtain secondary resources from the existing publications that are available in the books, journals in internet and in the library in Taipei. Besides, a field research was conducted to collect primary data by doing some interviews. Location for the field research was done in Taipei and Taichung cities. Both regions are among big cities in Taiwan that become the main tourism destinations in Taiwan. Hence, it is assumed that these districts have also developed their halal tourism industry. According to a report published by global market research firm Euromonitor International, in 2015 Taipei and Taichung ranked $14^{\text {th }}$ and $97^{\text {th }}$ as the most popular cities for visitor that received 
9.04 million and 1.98 million visitors, respectively [16]. The field research was conducted for a month in total, from August 5 to September 4, 2018.

Structured interviews with some stakeholders with the total number of 27 informants were conducted including with the Taiwan representative officers (4) (IETO, the Bureau of Tourism - Taiwan Ministry of Transportation and Communication, district representative officers from the Bureau of Tourism of Taipei and Taichung Cities), businessman run in the restaurant (8) and accommodation (1), the halal certification bodies (Chinese Muslim Association/CMA, the Taipei Grand Mosque/TGM), and the other body, some Taiwanese and Indonesian residing in Taiwan as well as scholars (10).

All of the interviews were digitally recorded and were transcript following the interviews. To avoid misinterpretation of the substance of the interviews in Mandarin Language, a local assistant was hired. To enrich the knowledge on halal according to Islam, I also attended a public lecture series given by the director of Halal Center of Gadjah Mada University at the "SendaNgaji" Islamic community in Jogjakarta.

Analysis of the research from the perspective of businessman is done descriptively analysis by using policy approaches.

\subsection{Definition of Halal Tourism}

There are many definitions about halal tourism [17][18]. Some scholars use term of "Islamic tourism" as they think both can be interchangeable though they can also be confusing [13]. However, actually Halal tourism is different from the religious tourism [6]. Religious tourism is any kind of tour that is motivated partly or exclusively for religious reason (Rinschede as cited by Jaelani [10]). According to Battour [17], halal tourism is all tourism activities, facilities, actions and objectives that are permissible according to Islamic Law (Sharia). When doing something, a Muslim has to consider Syaria or Islamic law, including in tourism.

Halal tourism is a relatively newly concept so that there is a challenge in defining the right term and the proper clarification of halal tourism. According to Djakfar [6], halal tourism is various kinds of tourism activities which are supported by various facilities and services from the community, entrepreneurs, government (central and regional) in accordance with Syaria principles. However, Djakfar [6] explains that halal tourism has different characteristic from the conventional tourism. Hence, it has difference consequence for the involved stake holders. Taiwan itself defines the halal tourism similar to the general tourism but there are extended services for the Muslim visitors.

\subsection{Halal Tourism Policy in Taiwan}

Morris in Ashman (2010) defines a policy as a regulation that regulates one's life and determines expectation to behave. A policy determines how government, society and organization run within a predictable and coordinated way. Goeldner and Ritchie [19] define tourism policy as any kind of regulation, guidance, direction, and development goals, promotion and strategy for decision making either for individual or collective that gives direct influence to tourism development in the long-term and daily activities in a tourist destination. In addition, Biederman [20] defines tourism policy as a plan direction used either by a country, region, locality or even individual destination to develop or to promote tourism. With the policy, there supposed to be maximum social and economic benefits that would be gained by nation, region or locality from tourism.

Since the launch of the New Southbound Policy (NSP) in Taiwan in 2016, the development of the halal tourism industry has been included as one of the platforms of the policy. Since then, 
it has been developed more intensively. Basically, NSP constitutes Taiwan's strategy to establish a long-term cooperation and to develop broad relations with countries in Southeast Asia, South Asia, New Zealand and Australia.

Tourism industry which plays significantly to Taiwan's economy was predominated by tourists from Mainland China ${ }^{2}$. However, due to the declining tourism market since the leadership of President Tsai Ing-wen, many experts have suggested the opening of new markets.

To build a strategic partnership that is expected to create regional prosperity, four tasks are performed under the NSP. First, by encouraging economic collaboration with the New Southbound countries, focusing on a) supply chains, b) domestic market demand, and infrastructure projects. Second, by carrying out talent exchange, by focusing on a) educational relationships, b) industry talent, and c) new immigrants. Third, resource sharing, by focusing on a) health care, b) culture, c) tourism, d) technology, and e) agriculture. Fourth, strengthening regional relations, by focusing on a) regional integration, b) negotiations and dialogue, c) strategic alliances, and d) Taiwanese networks abroad. Hence, the development of the halal tourism industry constitutes as the implementation of the 3rd task of the NSP, namely resources sharing.

Several reasons have attracted the Taiwan authority to pay more attention to Muslim visitors. Eric Lin, the Director of International Affairs Division, Taiwan Tourism Bureau, during the interview with Bahardeen [21] mentioned some factors. First, is number and the growth of the population of Muslim in the world. Second, is due to the changing of people's life style. The newly rich people in Muslim countries now see traveling as a necessity of living, so the traveling population has grown fast. Third, Muslims like to travel with families and would like to know the latest and most popular destinations. Fourth, a lot of Muslim family would like to look for experience that relevant to Islamic values [22]. This trend has also attracted some other countries whose population is non-Muslim majority, such as Thailand ${ }^{3}$, Singapore, Japan, and South Korea to create halal tourism industry which later on they may become Taiwan's competitors or partners.

\section{Result and Discussion}

As the Halal Tourism Industry development is included in the NSP, its development industry in Taiwan has been supported by policy. However, instead of providing law or regulation on it, Taiwan authority only provides general policy to some stakeholders. To attract inbound Muslim tourists, two kinds of policies have been issued, namely halal certification policy and creating a Muslim-friendly environment.

Implementation of the halal tourism industry is coordinated by the Ministry of Transportation and Communication while the developments of the halal tourism in Taipei city and Taichung city are under the coordination of the Tourism Bureau of the Taipei city and Taichung city, respectively. However, the implementation in the regions highly depends on the readiness of the district itself. In fact, Taipei City is more ready compared to Taichung City.

\footnotetext{
${ }^{2}$ Ma Ying-jeou, the former President made easier entry barriers for mainland Chinese group tourists to visit Taiwan. The aim was to improve cross-strait relations. As a result, tourists from Mainland China increased from 289,000 in 2008 to more than 4 million people in 2015 . This number represents $40 \%$ of the total inbound tourists in the same year. The influx of Mainland Chinese tourists is certainly a big contribution to Taiwan's economy. According to statistics, the estimated total expenditure of mainland Chinese tourists was USD 198.43 in 2016 or the second largest after tourists from Japan. Most expenses come from consumer goods, accommodation, and food.

${ }^{3}$ Thailand has developed a tourism program of Syaria spa since 2012 [22].
} 
Since 2009 Taiwan has begun to initiate the development of Muslim-friendly tourism, as delivered by the Chinese Muslim Association (CMA), an institution that is given authority for managing Muslim affairs in Taiwan. This was indicated from the brochure published by the CMA. However, only in 2013 Taiwan officially announced the development of Muslim-friendly tourism through its tourism policy, mentioning that Taiwan would target more Muslim tourists. However, there were not many actions to support the development of the industry development. As a result, from 2009 to 2016 the development of the halal tourism industry in Taiwan was stagnant. Perhaps this is the factor why Taiwan's halal tourism industry had not shown any significant development. Besides, concept of the halal tourism was just a new concept so it was not popular yet. For example, the number of restaurants that received halal certification was very limited. Even, there was no data that recorded the Muslim friendly accommodations in Taiwan. Since 2013 the development of halal tourism did not change so much.

After 2016, the development of the halal tourism industry was more significant as it was included as one of the platforms of the NSP. The NSP defines efforts of resource sharing in the field of tourism that aims to promote halal tourism industry and to export Taiwan halal products. Encouraging companies to get halal certifications is very necessary, and so does to get the halal certified products for export and domestic markets. These strategies are expected to create Muslim friendly environment and thus enable to attract more inbound tourists into Taiwan. To export Taiwan halal products, in 2017 Taiwan Halal Center (THC) was established under the Taiwan External Trade Development Council (TAITRA).

Though the NSP has mentioned the priority areas for halal tourism development, there is no explicit policy like law or regulation to develop halal industry and exact plan of action on how to support the policy implementation [12]. However, the establishment of THC at least can be an indication of the Taiwan's transformation toward a Muslim friendly tourism.

In order to promote the halal certification, the Ministry of Tourism Bureau has cooperated with the private institutions to manage it, in which Taiwan administration relies on these groups very much.

Some institutions that have authority to give halal certifications in Taiwan are: the CMA, Taipei Grand Mosque (TGM), and the Taiwan Integrity Development Association (THIDA) (Taiwan Halal Center, 2019). Only in 2017 the other new authority for halal certification, namely Sincung Halal for Taiwan Co., Ltd was established (Taiwan Halal Center, 2019). Thus, overall, there are four official halal certification institutions in Taiwan. Each institution has a slightly different scope of authority. Besides, it also has different halal certificate logo.

These institutions have collaborated with international halal certification bodies, including the Malaysian Islamic Progress Position (JAKIM) - Malaysia, the Indonesian Ulema Council (MUI), and the Singapore Islamic Ulema Council (MUIS) (Taiwan Halal Center, 2019).

The CMA which was established in 1958 is the main body for administering the affairs of Muslims in Taiwan and Taiwan administration. Its location is in the Taipei Grand MosqueTaipei.

The other halal certification body is the Taipei Grand Mosque, particularly for the manufacturers. Together with the other five mosques in Taiwan, including the Taipei Cultural Mosque, Long Gang, Dayuan, Taichung, and Kaoshiung mosques, they can issue halal certificate. Previously, they give the halal certificate to Muslim owner only based on trust. However, since in 1990s more non-Muslim owners wanted to get the certificate halal certification was given in the writing form Setyaningsih [23].

In 1993 for the first time the Taiwanese halal logo was developed and was used as the halal stamp certificate [12]. Previously, manufacturers had to pay for NTD 20,000 to get the halal certificate from CMA and TGM, but since 2011 TGM only focuses on the manufacturers. 
Whereas, the local mosque focuses on giving that of the slaughterhouse and halal restaurant operated by Muslims. In 2012 the TGM Foundation issued its own halal certification logo. In late 2011 the Taiwan Integrity Development Association (THIDA) began to issue its own halal certification, after it received approval from JAKIM, MUI and MUIS. Hence, there were three bodies that can issue halal certificate, namely the CMA, TGM and the other mosques, the mosques and THIDA.

By 2017, there were four halal certification bodies in Taiwan, namely the CMA that focuses on the local service, including restaurant, kitchens, hotels, and other tourism players. TGM focuses on giving halal certificate to local services and manufacturing companies. THIDA concentrates on the manufacturer products and Sincung that works with Indonesia Ulema Council (MUI).

There are five kinds of halal certifications, namely: Muslim Restaurant (MR), Muslim Friendly Restaurant (MFR), Muslim Friendly Tourism (MFT), Halal Kitchen (HK) and Muslim Friendly Tour Guide (MFTG). MR refers to restaurant that belongs to a Muslim owner, while the MFR refers to that belongs to a non-Muslim owner. MFT refers to any accommodation that received halal certification, whereas the HK provides halal catering service for the tourist hotel industry, hotel industry, and sightseeing and amusement industry. The last one is MFTG, certificate for tour guide, as she or he is an actor that will guide the tourists during traveling in Taiwan.

According to the CMA, until 2017, there has been at least 100 halal certified eateries and accommodation in Taiwan, consist of 30 halal restaurants, 20 Muslim-friendly restaurants, and 30 Muslim-friendly hotels in Taiwan out of about 550 hotels. The number increased to 200 in 2018.

Those hotels and restaurants spread all over Taiwan. However, in term of the quantity, the number in Taipei is higher. It is not wondering, since Taipei is a capital city; as a consequence, more facilities are available there. Besides, Taipei is the biggest city in and becomes the top tourist destination in Taiwan, followed by Kaoshiung and Taichung. Hence, Taipei can be a benchmark as the halal tourism development.

Amongst the halal or Muslim friendly restaurants in Taiwan, most of them provide various menus, ranging from Asian, including the Middle East, India, Pakistan and Indonesian. Only a few numbers of the restaurants that provide Chinese or Taiwanese menus. Most of the restaurants are in the scale of Small and Medium Enterprises (SMEs) as they become the characteristic of enterprises in Taiwan. The limited number of the halal local culinary becomes challenge in developing the halal tourism industry since Taiwan has gastronomy destination identity that has various and different local foods. Meanwhile, participating in the local festivals, gourmet tours and holidays are the most attractive factor of tourist's experience (Lin, 2015). In addition, the Bureau of Tourism has determined night market is one of the must-visited places for tourists to enjoy Taiwan because it serves many kinds of local authentic local foods. However, only a few numbers of the food stalls that have halal certification. This becomes barriers for the Muslim tourists to enjoy the halal locality taste of Taiwan.

The Muslim Business Traveler Insights 2016 (透視穆斯林商務旅客) released in October 2016 stated that while $43 \%$ of Muslim travelers only dine in restaurants that solely serve halal food, $44 \%$ of them are willing to accept eateries that clearly label -non-Muslim food and -Pork-containing dish on their menus (https://www.travel.taipei/en/news/details/9014, 2016). To help the Muslim friendly tourists, non-alcohol and pork free stickers may help them to understand the content.

To obtain halal certification from the authority, there are some processes of investigations that must be followed by the restaurants. The CMA gives training to the cook, the employee 
who gives services to the Muslim guests, and the management staff about Islam and the other knowledge that they need if they receive Muslim tourists. The training is usually done in Taipei city, where the office of the CMA exists and is followed by representative officers from the hotel or restaurant. However, for those who stay in other cities, the hotel or restaurant owner can also host the training, but can be attended by most of the staffs. After that, they will proceed to provide symbol or sign of halal logo that active for one year. After one year, they do not need to follow training. It is only when there is a shift of their staff, which is very often, they have to follow the training again. In giving the halal certification, the authority does not request any charge, excluded the training process.

To promote the Muslim Friendly Restaurant, the Taiwan administration has provided subsidy. The subsidy is aimed to assist the aspects of equipment needed, and the other staffs in which each of them is paid $50 \%$ of the amount of expenditure. They need to apply for this subsidy by fulfilling the requirements as available in their website (http://admin.taiwan.net.tw/law/law_en.aspx?no=9). Two categories of the subsidies are available, namely subsidy for the restaurant that has 30-50 seats and for the one that has 50 seats and more.

The first category will receive subsidy of NT 100.000 while the second one will receive NT 200.000 for the maximum. Since the annual budget is limited to NT\$ 10 million only, so the application for the subsidy is limited to one time. A team of reviewer, which consists of experts from the bureau, hotel management, kitchen affairs and electromechanical planning, and CMA will review the application for giving approval. Those who passed the review will be granted; in contrast those who lose the halal certification have to return the subsidy. However, this information is not well informed to all of the restaurant owners [23]. Besides, giving subsidy is considered as a short-term solving problem to increase number of the halal restaurant, but does not guarantee a long-term sustainability.

The problems that may be faced by the CMA is in controlling the validity of the certified restaurant/hotel. After the hotels /restaurants received their certificate, an agreement is issued by the halal certification body and the owner. The owner has to follow the regulation. In case there is a violation against the rule, the CMA will send a card to them and they have to pay the fine. In fact, many of the restaurant owners do not extent the certificate once it is expired. The CMA implements an online system which will automatically remind the business owner about the validity of the halal certificate. This notification can is also available in the tourism bureau website. In case the business owner does not want to extend the expired certificate, they achieved, they just need to return it to the CMA.

Until 2018, there was less than $10 \%$ of the business owner who does not want to extend the validation. This is related to the internal policy of the hotel/restaurant. Besides, they think that the halal certificate does not increase number of customer [23].

To assist the hotel or restaurant to attract more customers, promotion is boosted by the authority under the - partnership with the local program. The CMA in co-operation with some travel agencies and the airplane companies introducing the Halal tourism in Taiwan. It is expected that the Muslim travelers will feel secure and safe about the halal things in Taiwan.

Besides, an Apps has also been created to facilitate the visitors during staying in Taiwan. This Apps provides information about halal restaurants, Muslim friendly accommodations, praying schedule, and anything about Taiwan Halal tourism. 


\subsection{Promoting Halal Tourism Industry and Muslim Friendly Environment}

There are several kinds of efforts that have been done to promote the halal tourism industry and Muslim friendly environment. To attract more inbound tourists to Taiwan, easy procedures for applying visa has been made for South East Asian citizens. For example, since 2017 the Indonesian who hold permanent residence permits issued by Taiwan, the US, Canada, Australia New Zealand, Japan, Korea, Britain, or Schengen Agreement signatories or those hold a visa or valid residence permits from one of those countries that is valid or that expired within 10 years of the date expected to arrive in Taiwan and whose do not have record of violating Taiwan's law, can apply visa on the website of the Immigration Department of the Taiwan Ministry of Interior.

When the Muslim tourists have already been in Taiwan, some facilitations have been prepared. To ease Muslims to perform pray, the bureau of Tourism has encouraged public transportation facilities and scenic spots to build prayer rooms and wash lets. Until 2017, lots of public spaces are equipped with prayer rooms. For example, the 13 National Scenic Areas, Taoyuan International Airport, Kaohsiung International Airport, Taipei Train Station, Kaohsiung Train Station, and Taiwan High Speed Rail Taichung Station, all have Muslimfriendly facilities. Besides, some public places have also been equipped with prayer room as well. For example, in the second floor of the Discovery Center of Taipei, the National Palace Museum in Taipei, shopping mall Taipei 101, Alishan National Scenic Area in Chiayi County and Sun Moon Lake in Nantou County are also equipped with a Muslim prayer room. Compared to the situation in the last five years, the number of prayer rooms has increased significantly. These facilities are very important for Muslim travelers so they can do travelling and worship at the same time. In fact, this facilitation is also very beneficial to the Muslim residents, as well.

Besides, Taiwan has also given appreciation to Muslim big holidays like Ied Al Fitr by providing places for Muslim residents to celebrate it. On $6^{\text {th }}$ of July, 2016 at the first time the Taiwan administration formally announced that Eid al-fitr as an important Holiday for Muslim. The Taipei Grand Mosque Chairman at that time, Feng Tung-yu, urged employers and company executives to support Muslim workers to attend the Eid al-Fitr activities at mosques located close to them, to allow them complete their required lessons as a Muslim ${ }^{4}$. In 2017, President Tsai Ing-wen also gave speech to congratulate Muslims in Taiwan. In particular she also thanks to the Muslim workers who have contributed to the Taiwan cultural development. Besides, Mayor Ko Wen-Je, the mayor of Taipei City, also attended the celebration in the Taipei Grand Mosque \& passed out Hong bao to Indonesian workers in Taipei. In addition to these, some programs and information have also been broadcasted through television. The programs that introduce the Southeast Asian countries' cultures also introduce Indonesian Muslim's cultures. As a result, these also affect the Taiwanese's understanding toward Muslim. All of these efforts need to be appreciated.

Regardless the increasing trend of Muslim tourist in the future, Taiwan businessman still concentrate on non-Muslim customers. Besides, the various local culinary of Taiwanese are supposed to be resources that can be utilized to attract more Muslim tourists into Taiwan.

In fact, at the early stage of the development, visitors coming from the Muslim-majority countries were still limited. According to the data, in 2016 around 200,000 of the 10.44 million visitors or almost $2 \%$, coming into Taiwan were Muslim Visitors. They were mostly come from Malaysia, Singapore, Indonesia, India, and the Philippines. Only a few people came from the

${ }^{4}$ http://www.moi.gov.tw/english/english_news/news_detail.aspx?sn=16227\&type=taiwan\&pages=0. Accessed on July $15,2016$. 
Middle East, whose number was as less than $2 \%$ of the total foreign visitors. This small amount of number of the Muslim visitors to Taiwan made disappointment expressed by businesses in the tourism sector due to their poor return on their investment [21]. Factor that may contribute to this small number was related to the relatively new established of the industry, hence this has made the investors still focus on the non-Muslim visitors.

However, number of the Muslim visitors is expected to increase year by year, in line with the increasing effort of Taiwan side to create better environment to Muslim. Responding to the issue, the Tourism Bureau Deputy Director said that based on the history, Taiwan itself needed over 10 years to grow the number of Japanese visitors so that in 2015 the number of it reached 1.63 million. Meanwhile, the Muslim tourism has just started recently and thus it will need more time to attract more tourists.

Until April 2017, visitor arrivals from Southeast Asia increased 38.6\% year on year to about 675,000 . Of this total, number of the visitors from Malaysia and Singapore increased by $14 \%$ and $10 \%$, to about 172,000 and 127,000 , respectively. Meanwhile, visitors from Indonesia increased to more than $6 \%$ annually to almost 189,000 . It is expected that in 2018 the number will increase to reach 250,000 visitors [24].

However, it must be confessed that regarding the number of the Muslim visitors, it is difficult to get the actual number. Until nowadays, there has been no exact database on the data of Muslim visitors coming into Taiwan [23]. The Bureau of Tourism under the Ministry of Transportation and Communications has been only making assumption based on the visitors coming from Muslim majority-countries.

In term of the development of halal tourism industry, Taipei city is the most developed one. As the capital city of Taiwan, the availability of halal restaurants and Muslim friendly accommodations are higher. Among the halal-certified services, Taipei city makes $60 \%$. In contrast, the Taichung government has been trying to develop its tourism industry. As the third largest tourist destination in Taiwan, Taichung administration has been trying to attract more tourists coming into Taichung. In Mandarin, Taichung [台中/Taizhong] means center of Taiwan. Most of tourists coming into Taiwan often set their destination from Taipei to Kaoshiung. As a result, Taichung is just a crossing area for tourists. Hence, the focus of the administration is how to attract more tourists to visit Taichung.

\section{Conclusion}

After 3 years of the NSP, the Halal tourism industry in Taiwan has still at the beginning stage of development. It still needs time to develop successfully. Among the southeast Asian countries, Indonesia Muslim tourist is the target for the Halal tourism in Taiwan since its society is not strict and more open to the Muslim-friendly category. However, no database available on the exact number of the Muslim tourists coming into Taiwan.

Since Taiwan is not Muslim-majority region, role of the religious organization is very important in giving authority of halal certification. However, there is no explicit halal industry development policy and exact plan of action how to support the policy implementation. Four main bodies that give halal certification have their own roles in giving the certificate. The effort to create Muslim-friendly environment promote Muslim-friendly

Regardless the increasing trend of Muslim tourist in the future, Taiwan businessman still concentrate on non-Muslim customers. Besides, the various local culinary of Taiwanese are supposed to be resources that can be utilized to attract more Muslim tourists into Taiwan. 


\section{Acknowledgement}

This research was supported by POSCO Asia Forum of POSCO TJ Park Foundation 2018. I would like to thank Professor Tsay Ching-lung, Professor Emeritus from the Department of Diplomacy and International Relation, Tamkang University, Taipei, to my colleagues Dr. Yani Mulyaningsih from the Research Center of Economics of Indonesian Institute of Sciences who provided insight and expertise that greatly assisted the research. I thank Dr. Wuryandari, as the director of the Center for Area Studies as well as Dr. Cahyo Pamungkas for supporting my research.

\section{References}

[1] A. Mohsin, N. Ramli, and B. A. Alkhulayfi, "Halal tourism: Emerging opportunities," Tour. Manag. Perspect., vol. 19, pp. 137-143, 2016.

[2] M. H. Kamali, "Tourism and the Halal Industry: A Global Shari'ah Perspective," ICR J., vol. 3, no. 3, pp. 456-473, 2012.

[3] Hackett, Conrad, Mcclendon, and David, "Christians remain world's largest religious group, but they are declining in Europe," Pewresearch, 2017. [Online]. Available: http://www.pewresearch.org/fact-tank/2017/04/05/christians-remain-worlds-largest-religiousgroup-but-they-are-declining-in-europe.

[4] Pew Research Center, "The Future of the Global Muslim Population," Pew Research Center, 2011. [Online]. Available: https://www.pewforum.org/2011/01/27/the-future-of-the-globalmuslim-population.

[5] Crescent Rating Global Muslim Travel Index (GMTI), "Mastercard Crescentrating Global Muslim Travel Index 2017," Crescent Rating Global Muslim Travel Index (GMTI), 2017. [Online]. Available: https://www.crescentrating.com/reports/mastercard-crescentrating-globalmuslim-travel-index-gmti-2017.html.

[6] M. Djakfar, Pariwisata halal perspektif multidimensi: peta jalan menuju pengembangan akademik \& industri halal di Indonesia. UIN-maliki Press, 2017.

[7] Halal Trip, "Muslim Millennial Traveller Report 2017," Halal Trip, 2018. [Online]. Available: https://www.halaltrip.com/halal-travel/muslim-millennial-travel-report.

[8] S. Zailani, A. Omar, and S. Kopong, "An exploratory study on the factors influencing the noncompliance to halal among hoteliers in Malaysia," Int. Bus. Manag., vol. 5, no. 1, pp. 1-12, 2011.

[9] Z. Samori, N. Z. M. Salleh, and M. M. Khalid, "Current trends on Halal tourism: Cases on selected Asian countries,” Tour. Manag. Perspect., vol. 19, pp. 131-136, 2016.

[10] A. Jaelani, "Halal tourism industry in Indonesia: Potential and prospects," Int. Rev. Manag. Mark., vol. 7, no. 3, 2017.

[11] J. C. Henderson, "Halal food, certification and halal tourism: Insights from Malaysia and Singapore," Tour. Manag. Perspect., vol. 19, pp. 160-164, 2016.

[12] K. A. Adham, "Halal Taiwan: Emerging Player in the Global Halal Market. Report for Taiwan's Ministry of Foreign Affairs (MOFA) Visiting Scholar," Taiwan ASEAN Stud. Center, ChungHua Inst. Econ. Res., 2017.

[13] M. Battour and M. N. Ismail, "Halal tourism: Concepts, practises, challenges and future," Tour. Manag. Perspect., vol. 19, pp. 150-154, 2016.

[14] S.-H. Yang, "Do traditional market consumers care about the halal meat label? A case study in Taiwan," Int. Food Agribus. Manag. Rev., vol. 22, no. 1030-2019-3339, pp. 781-794, 2019.

[15] G. Yilmaz and S. Gültekin, "Global issue and trends in tourism," 2016.

[16] Focustaiwan.tw, "Taipei the 14th most popular city for visitors: Euromonitor," Focustaiwan.tw, 2017. [Online]. Available: http://focustaiwan.tw/news/asoc/201701280010.aspx.

[17] M. M. Battour, "Muslim Friendly Tourism," 2016.

[18] I. M. Hamza, "Islamic tourism: Exploring perceptions \& possibilities in Egypt," African J. Bus. 
Econ. Res., vol. 7, no. 1, pp. 85-98, 2012.

[19] C. R. Goeldner and J. R. B. Ritchie, Tourism principles, practices, philosophies. John Wiley \& Sons, 2007.

[20] P. S. Biederman and P. S. Biederman, Travel and tourism: An industry primer. Pearson/Prentice Hall Upper Saddle River, NJ, 2008.

[21] F. Bahardeen, "Interview: Focus on the Muslim Travellers at Taiwan Tourism Bureau," 2016. [Online]. Available: https://www.crescentrating.com/magazine/crescentratinginterviews/3883/interview-focus-on-the-muslim-travellers-at-taiwan-tourism-bureau.html.

[22] Kajian Ekonomi Islam Fakultas Ekonomi dan Bisnis-Universitas Sebelas Maret Surakarta (KEI FEB UNS), "Potensi Halal Tourism di Indonesia," 2016.

[23] E. D. Setyaningsih and S. Marwansyah, "The Effect of Halal Certification and Halal Awareness through Interest in Decisions on Buying Halal Food Products," Syiar Iqtishadi J. Islam. Econ. Financ. Bank., vol. 3, no. 1, pp. 65-79, 2019.

[24] L. W. Ambari, "Taiwan offers halal tourism to Indonesian," ANTARANews.com, 2018. [Online]. Available: https://en.antaranews.com/news/119137/taiwan-offers-halal-tourism-to-indonesians. 